\title{
Determinants of Job Performance of Cabin Crew on Customer Service of an Aircraft: A Conceptual and Empirical Study in Sri Lanka
}

\author{
H.H.D.N.P. Opatha \\ Senior Professor \\ Faculty of Management Studies and Commerce, \\ University of Sri Jayewardenepura, Sri Lanka \\ opatha@sjp.ac.lk
}

Sanjeewa Rathnayake

MBA Scholar

Faculty of Social Sciences and Humanities,

Open University of Sri Lanka

sanjeewa.rathnayake2010@gmail.com

Cite this article: Opatha, H.H.D.N.P. and Rathnayake, S. (2018), Determinants of Job Performance of Cabin Crew on Customer Service of an Aircraft: A Conceptual and Empirical Study, Sri Lankan Journal of Human Resource Management, Vol. 8, No. 1, pp. 1-21. 


\begin{abstract}
Little research has been done with regard to determinants of job performance of Cabin Crew working in an airline. Further it revealed that a contextual gap and an intellectual curiosity exist with regard to the determinants of job performance of these employees from the perception of relevant stakeholders. A systematic desk study was carried out to find answers for two conceptual research questions and interviews with 20 stakeholders, observations of three critical incidents, and administration of an interview evaluation sheet to ten resource personnel were done to find answers for three empirical research questions. The empirical findings revealed that job performance of the Cabin Crew on customer service of an airplane in an airline is very important as the work is pivotal and core; there are a variety of common and specific factors which may affect job performance of the Cabin Crew on customer service of an airplane, 14 factors were finalized as per the perception of different stakeholders; 8 factors were identified as major determinants; and the most important three factors from the finalized 14 factors were attitude about customers, agreeableness, and competencies according to the prioritization of the resource personnel. It is implied that attitude about customers, agreeableness, and competencies are built through right training; measured and improved through right performance evaluation; and reinforced through right reward management. As a proactive strategy, to have recruitment and selection to ensure that right people enter the organization in terms of these three factors needs to be done.
\end{abstract}

Key Words: Airline, Cabin Crew, Determinants, Job Performance

\title{
Introduction
}

Job performance is a critical phenomenon in Human Resource Management (HRM), Organizational Behaviour, and General Management literature and is generally considered as a vital output or outcome. Job performance is the key dependent or predicted measure of management and it serves as the vehicle for judging the effectiveness of individuals, groups, and organizations (Szilagyi, 1981). An examination of past studies reveals that job performance is one of the most extensively research phenomenon, it works as an outcome or a consequence of many variables in many studies, it can be considered as an intervening variable, and summation of individual performance makes organizational performance or business performance (Ramawickrama, Opatha, and PushpaKumari, 2017). Little research has been done with regard to determinants of job performance of air employees working in an airline, which is an organization that provides aircraft services for passengers and goods in Sri Lanka, perhaps in Asia. In particular it reveals a gap in the empirical knowledge of the determinants of job performance of the Cabin Crew on customer service of an aircraft in airline industry in Sri Lanka indicating a contextual gap in research too. In addition, there is an intellectual curiosity to know factors and major factors which determine or contribute to job performance of the Cabin Crew on customer service of an airplane in an airline that is a key organization for socio-economic development of Sri Lanka. 


\section{Research Questions and Objectives}

A systematic attempt was made to find answers for the following research questions:

1. Is job performance of the Cabin Crew on customer service of an airplane in an airline important or very important?

2. What may be the factors which determine job performance of the Cabin Crew on customer service of an airplane?

3. What are the possible factors which determine job performance of the Cabin Crew on customer service of an airplane as per the perception of different stakeholders?

4. What are the major factors which determine job performance of the Cabin Crew on customer service of an airplane as per the prioritization of managers and instructors who are responsible for performance management of the crew?

5. What are the three most important determinants of job performance of the Cabin Crew on customer service of an airplane as per the prioritization of managers and instructors who are responsible for performance management of the crew?

This study has two parts, i.e. a conceptual part and an empirical part as well. The first and second questions mentioned above deal with the conceptual part of this study while the rest of the questions (numbered 3, 4, and 5) deal with the empirical part of the study. In order to find answers for the above mentioned research questions following objectives which are consistent with the specified research questions were established for the study:

1. To ascertain whether job performance of the Cabin Crew on customer service of an airplane in an airline is important or very important.

2. To explore and identify the factors which may determine job performance of the Cabin Crew on customer service of an airplane.

3. To find out the possible factors which determine job performance of the Cabin Crew on customer service of an airplane as per the perception of different stakeholders.

4. To find out the major factors which determine job performance of the Cabin Crew on customer service of an airplane as per the prioritization of managers and instructors who are responsible for performance management of the crew.

5. To find out the three most important determinants of job performance of the Cabin Crew on customer service of an airplane as per the prioritization of managers and instructors who are responsible for performance management of the crew.

\section{Method}

As this study is a systematic attempt to answer the above mentioned five research questions, a desk research and an empirical study were conducted. In order to find systematically answers for research questions numbered 1 and 2 the desk research was conducted. A methodological review of existent literature available to the researchers was done hereby. It was mainly based on well known textbooks (authorities). For the purpose of finding an answer for research question numbered 3, the interview method was applied. Relevant people who interacted directly with the Cabin Crew were here relevant 
stakeholders and they included 5 managers, 5 cabin managers, 5 flight stewardesses, and 5 customers. An equal number from each party was taken on the convenient basis from the application of $360^{\circ}$ perspective. In addition to these parties, the observation method was done and it was performed by one of the two researchers of this study who is an In-Flight Service Instructor of the airline that was the case organization considered for this study to carry out the empirical part. In case of finding an answer for research questions numbered 4 and 5 an evaluation sheet was prepared and it was presented to 6 senior managers and 4 instructors, who were responsible for performance management of the crew, for the purpose of prioritizing. These respondents were indeed well-experienced and highly knowledgeable about the determinants of job performance of the Cabin Crew on customer service of an aircraft.

\section{Conceptual Part}

\section{Job Performance of the Cabin Crew and Its Importance for an Airline}

The first research question of the study is: Is job performance of the Cabin Crew on customer service of an airplane in an airline important or very important? Job performance is indeed an abstract concept and hence it has been defined by different scholars in different ways indicating that a universally accepted definition does not exist. Job performance is the single outcome of an employee's work (Hunter, 1986); includes behaviours or actions that are relevant to the goals of the organization (Campbell, 1990); is the record of outcomes produced on a specified job function or activity during a specified time period (Bernardin and Russell, 1993); refers to scalable actions, behaviour and outcomes that employees engage in or bring about that are linked with and contribute to organizational goals (Viswesvaran and Ones, 2000); is the sum of behaviours of employees (Griffin, Neal, and Parker (2007); is the contribution that individuals make to the organization that employs them (Stewart and Brown, 2014); is the extent to which duties and responsibilities have been carried out (Opatha, 2015); and is the extent to which the employee has shown his or her traits, engaged in behaviours and produced results which are appropriate to task performance, and has engaged in citizenship performance and counterproductive performance during a particular period of time (Ramawickrama, et al, 2017). Thus, job performance includes traits or qualities possessed by the employee, actions or behaviours done or engaged by the employee, and the results produced by the employee. Whatever may be the definition of job performance it is generally very important for the employee's effectiveness, his or her team's effectiveness, and overall effectiveness of the organization where he or she works.

Without satisfying customers, there is no possibility of stopping that a business will cease to exist. According to DuBrin (2009), studies indicate that an upset or angry customer tells an average of between 10 and 20 other people about an unhappy experience; and customer satisfaction is highly valued because it breeds customer loyalty, which in turn is very profitable-Repeat business is a success factor in both retail and industrial companies. By discussing about understanding business Das (2004, p. 11) concludes: 
"First... Customers and Employees are the most important stakeholders in any business. Second... Customers are the ends of the business. Employees are the means. Organisations having satisfied employees create satisfied customers."

According to Anastasiou and Nathanailides (2015), service provided by employees helps to build a good relationship with customers and can help at increasing their loyalty. A satisfied customer will continue to buy the product (good or service); will tell his or her friends and acquaintances about the product that gave the satisfaction resulting in stimulating others to buy; will or may give feedback so as to improve the product further; and thus a satisfied customer is the key driver of profits of the business organization. Kiger (2002) emphasizes that customer satisfaction starts with human resources. He further underlines that there is convincing evidence that employees drive customer satisfaction- and corporate revenues-by careful attention to who is hired, how they are trained, how they are coached, and how they are treated on the job. What employees perform determines customer satisfaction, and also how employees perform determines customer satisfaction. Herb Kelleher, Chief Executive Officer of Southwest Airline expressed "We owe our success to our people" (Schuler, 1998). Schuler (1998, p. 3) writes:

"At Southwest Airlines, Herb Kelleher believes and acts in ways that demonstrate the company's belief in the importance of people (associates) to the business. This gives associates reason to believe and trust the company. In return, the associates deliver high-quality, friendly, and knowledgeable service - the essence of airlines according to Herb Kelleher."

An airline is a service based organization whose success is mainly impacted by the quality of the employees working. An airline is a business organization or company that provides aircraft services for passengers and goods. Success and progress of success of an airline depend heavily on right employees it has. The airlines throughout the world continuously strive to develop services which attract and keep customers who are satisfied, loyal, and speak well. To deliver a high quality service to passengers is vital for an airline to survive, and advance through gaining a competitive advantage which is sustainable. 'In-Flight Service' is being increasingly viewed as a competitive marketing strategy to create new customers while maintaining old customers. It is a core business function in an airline. It is the Cabin Crew that gives 'In-Flight Service'. Cabin is an area inside an aircraft and it is a place where passengers sit, and Cabin Crew are the employees who engage in serving the passengers. An alternative term is Aircrew and these employees are supposed to look after the passengers mainly. The frontline service staff can be crucially important for a firm's competitive positioning because the frontline is a core part of the product; hence they represent the firm and play the role of 'brand ambassadors' too (Heracleous, Wirtz, and Pangankar, 2009).

Empirical evidence shows that, when employees are able to deliver high quality service, customers are more likely to generate favourable evaluations of service encounters, experience higher satisfaction, and increase their purchases and the frequency of their future visits (Bowen, Siehl, and Schneider, 1989; Borucki and Burke, 1999). Front-line service 
employees, placed at the organization-customer interface and representing the organization to its customers, play a pivotal role in service encounters, which often dyadic interactions between customers and service employees (Solomon, Suprenant, Czepiel, and Gutman, 1985).

Dessler (2013) gives an approach about how to segment employees in an organization and according to which there are four types of employees such as mission-critical, core, necessary, and nonessential. As far as an airline is concerned, Cabin Crew is employees who are mission-critical. These employees will never become non-essential or outsourceable and they are closest to the mission-critical work of an airline.

Thus, job performance of the Cabin Crew on customer service of an airplane in an airline is very important.

\section{Possible Factors of Job Performance of the Cabin Crew on Customer Service of an Airplane}

The second research question of the study is: What may be the factors which determine job performance of the Cabin Crew on customer service of an airplane? A classic model of performance determinants developed by Larry Cummings and Donald Schwab (as in Glueck, 1978) presents ability of the employee, motivation of the employee, intrinsic outcomes (such as a good feeling experienced by a work-oriented employee who has done a good job or accomplished an important task), extrinsic outcomes (such as pay raises, promotions, and similar rewards), personal goal aspiration (goals sought by the employee to attain for herself or himself), and personal goal attainment (the goals the employee achieves).

Years of research show that five dimensions can summarize personality traits and they are called the Big Five factors which determine job performance of any employee and they include (1) Extroversion (the degree to which someone is talkative, sociable, active, aggressive, and excitable; (2) Agreeableness (the degree to which someone is trusting, amiable, generous, tolerant, honest, cooperative, and flexible); (3) Conscientiousness (the degree to which someone is dependable and organized and perseveres in task); (4) Neuroticism (the degree to which someone is secure, calm, independent, and autonomous); (5) Openness to Experience (the degree to which someone is intellectual, philosophical, insightful, creative, artistic and curious) (Judge and Bono, 2000). According to DuBrin (2000) dozens of factors can lower job performance and Exhibit 1 presents a comprehensive list of factors contributing to ineffective performance.

There are 27 factors contributing to ineffective job performance as per the Exhibit. These factors are common factors and it is possible to argue that they may be possible factors which determine job performance of Cabin Crew on customer service in an aircraft. Usually the true cause of ineffective performance is a combination of several factors (DuBrin, 2000). 
Exhibit 1: Factors Contributing to Ineffective Performance

\section{Factors Related to the Employee}

1. Insufficient mental ability and education

2. Insufficient job knowledge

3. Job stress or burnout

4. Low motivation and loafing

5. Technological obsolescence

6. Excessive absenteeism and tardiness

7. Emotional problem or personality disorder

8. Alcoholism and drug addiction

9. Tobacco addition or withdrawal symptoms

10. Conducting outside business on the job

11. Family and personal problems

12. Physical limitations

13. Preoccupying office romance

\section{Factors Related to the Job}

1. Ergonomics problems and cumulative trauma disorder

2. Repetitive, physically demanding job including heavy travel

3. Built-in conflict

4. Substandard industrial hygiene

5. A "sick" building

\section{Factors Related to the Manager}

1. Inadequate communication about job responsibilities

2. Inadequate feedback about job performance

3. Inappropriate leadership style

4. Bullying or intimidating manager

\section{Factors Related to the Organization}

1. Organizational culture that tolerates poor performance

2. Counterproductive work environment

3. Negative work group influences

4. Violence or threats of violence

5. Sexual harassment

Source: Adapted from DuBrin (2000) 
Kottawatta (2007) conducted a study that empirically investigated three attitudinal variables, which could influence on the job performance of the executive and non-executive employees in the apparel industry by collecting data from a randomly selected sample of 354 executive employees and 536 non - executive employees in the industry. The findings of the study were that job satisfaction, organizational commitment, and job involvement were positively and strongly correlated with job performance of executive employees as well as that of non-executive employees. Furthermore it was suggested that among the three attitudinal factors, especially job satisfaction should be considered to enhance the performance of executive and non-executive employees in this industry as a common attitudinal factor.

The above mentioned factors are common factors affecting job performance of any employee and, cabin crew is not an exception. Though it is the general perception that the flight attendants or the cabin crew of an airline do a 'glamorous job' and this job enables them to travel to places, meet different types of people, stay in luxury hotels and enjoy the realms which are very rare in other professions, it is possible to state that the job of a cabin crew member involves more than the 'glamour' involved in it. While, claiming all the above factors are true, being a cabin manager (cabin crew-in charge), second author of this paper wishes to stress that, the reality in the engagement as a flight attendant is 'no easy job' comparatively. The odd times of work (different flight schedules), different duty periods (depending on the flying time of the aircraft), different ergonomic conditions (different types of aircraft i.e., work environments), variety of the climatic conditions of the destinations (depending on the time of the year and the region) etc. make the job harder. Thus, a cabin crew member is supposed to be adjusted to these demands of the job while performing on the job. A variety of competencies (job knowledge, skills and abilities which are gained through experience), other attributes such as 'personality' factors and a great degree of 'motivation' are necessary to function as a successful cabin crew member on board of an aircraft which flies at an altitude of 40,000 feet above ground.

\section{Empirical Part}

\section{Possible Factors of Job Performance of the Cabin Crew on Customer Service of an Airplane as per the Perception of Different Stakeholders}

The third research question of the study is: What are the possible factors which determine job performance of the Cabin Crew on customer service of an airplane as per the perception of different stakeholders? The interviews were conducted by recording the data on a digital device and key words which were highlighted were captured as the elements or indicators which could contribute to the list of 'Possible factors' determining the job performance of the Cabin Crew. Summaries of responses (only eight, two from different stakeholders) are presented in Exhibit 2. 
Exhibit 2: Eight Summaries of Responses of Each Type of Stakeholders

\begin{tabular}{|c|c|c|}
\hline Interviewee & $\begin{array}{l}\text { Summarized Response (similar } \\
\text { responses were excluded) }\end{array}$ & Factor/s Identified \\
\hline $\begin{array}{l}\text { Manager } 1 \text { (Head } \\
\text { of Service Delivery) } \\
\text { Experience: } 30 \\
\text { years }\end{array}$ & $\begin{array}{l}\text { Crew needs to be committed to } \\
\text { customer satisfaction and each one } \\
\text { must have a right positive attitude } \\
\text { towards customers. Customers are the } \\
\text { king. Employees should protect the } \\
\text { company's good image. Competencies } \\
\text { are very important for their job } \\
\text { performance. }\end{array}$ & $\begin{array}{l}\text { Attitude about customers } \\
\text { Competencies }\end{array}$ \\
\hline $\begin{array}{l}\text { Manager } 2 \\
\text { (Manager In-Flight } \\
\text { Services Delivery) } \\
\text { Experience: } 33 \\
\text { years }\end{array}$ & $\begin{array}{l}\text { Our people should give customer care } \\
\text { and for that they should have } \\
\text { friendliness. They need to be } \\
\text { cooperative to each customer. Then } \\
\text { they will be able to provide an } \\
\text { excellent service to the customers. }\end{array}$ & $\begin{array}{l}\text { Caring } \\
\text { Friendliness } \\
\text { Cooperation }\end{array}$ \\
\hline $\begin{array}{l}\text { Cabin Manager } 1 \\
\text { Experience: } 27 \\
\text { years }\end{array}$ & $\begin{array}{l}\text { When recruiting and selecting the crew } \\
\text { knowledge and skills are to be } \\
\text { considered as they are contributing to } \\
\text { successful job performance. We don't } \\
\text { have a proper training in some cases } \\
\text { and it is a must for right job } \\
\text { performance. Career development and } \\
\text { performance evaluation are important. }\end{array}$ & $\begin{array}{l}\text { Competencies } \\
\text { Career development } \\
\text { Performance evaluation }\end{array}$ \\
\hline $\begin{array}{l}\text { Cabin Manager } 2 \\
\text { Experience: } 28 \\
\text { years }\end{array}$ & $\begin{array}{l}\text { Being 'friendly' is very important for } \\
\text { customer service. They should possess } \\
\text { good moral qualities. They should be } \\
\text { paid for what they do. What they get in } \\
\text { terms of incentives should depend on } \\
\text { what they perform. They must } \\
\text { maintain work-family balance. }\end{array}$ & $\begin{array}{l}\text { Friendliness } \\
\text { Personal character } \\
\text { Pay-for-performance } \\
\text { Work-Family Balance }\end{array}$ \\
\hline $\begin{array}{l}\text { Flight Stewardess } 1 \\
\text { Experience: } 07 \\
\text { years }\end{array}$ & $\begin{array}{l}\text { Be trustworthy. } \\
\text { Be calm. } \\
\text { Be involved. }\end{array}$ & $\begin{array}{l}\text { Trustworthiness } \\
\text { Calmness } \\
\text { Job involvement }\end{array}$ \\
\hline $\begin{array}{l}\text { Flight Stewardess } 2 \\
\text { Experience: } 14 \\
\text { months }\end{array}$ & $\begin{array}{l}\text { Making customers feel at home is } \\
\text { important. Previous experience in } \\
\text { customer service is important for good } \\
\text { job performance. Customer training is } \\
\text { critical. }\end{array}$ & $\begin{array}{l}\text { Attitude towards customer } \\
\text { Competencies }\end{array}$ \\
\hline $\begin{array}{l}\text { Customer } 1 \\
\text { Profession: } \\
\text { Executive Director }\end{array}$ & $\begin{array}{l}\text { Caring ability of the employees leads to } \\
\text { good job performance. Friendliness is } \\
\text { critical. When employees are happy it is }\end{array}$ & $\begin{array}{l}\text { Competencies } \\
\text { Friendliness } \\
\text { Job satisfaction }\end{array}$ \\
\hline
\end{tabular}




\begin{tabular}{|l|l|l|}
\hline & $\begin{array}{l}\text { easy for them to make customers } \\
\text { happy. }\end{array}$ & \\
\hline Customer 2 & $\begin{array}{l}\text { Crew should be knowledgeable of the } \\
\text { food and beverages. Great degree of } \\
\text { patience is needed for handling rude } \\
\text { customers. }\end{array}$ & $\begin{array}{l}\text { Competencies } \\
\text { Emotional stability }\end{array}$ \\
\hline
\end{tabular}

One of the researchers of this study engaged in certain observations for the purpose of finding possible factors which determine job performance of Cabin Crew. Three useful observations of critical incidents were possible and they are given in brief in Exhibit 3.

Exhibit 3: Three Observations of Critical Incidents

\begin{tabular}{|l|l|}
\hline Critical Incident & Factors Derived \\
\hline One: & Emotional stability \\
Some passengers who were male in the \\
Economy Class were demanding alcohol and \\
snacks throughout the flight journey. Crew \\
who were particularly junior in the rank \\
assigned in the middle galley found it \\
difficult to interact with o2 demanding & \\
customers when the choice of snacks was \\
run out. The customers scolded them and \\
they responded in somewhat loud way \\
(telling that "this is not a bar' and "behave \\
as gents").
\end{tabular}


The cabin manager intervened and the passenger was restrained to the seat. Upon landing, he was handed over to the local police. Later it was found that the supervisor in the forward cabin was not present to control the dispensing of alcohol and to monitor the passenger properly.

Based on the interviews and the observations of the three critical incidents it was possible to identify several factors which may determine job performance of Cabin Crew in general. They include attitude about customers, competencies, caring, friendliness, cooperation, career development, performance evaluation, personal character, pay-for-performance, work-family balance, trustworthiness, calmness, job involvement, job satisfaction, and emotional stability (after removing repetitions). The observations revealed emotional stability, attitude towards customers, supervision, knowledgeableness of every aspect of the job, discipline, supervision, empowerment of the subordinates to take swift decisions to mitigate issues, and adherence to rules of service. Attitude towards customers, emotional stability, and supervision are repetitions as they were found from the interviews also. In fact these factors derived from the observations are not possible factors but the factors which determined job performance during the critical incidents. Consequently the final list of the possible factors was prepared for the purpose of prioritizing. When preparing the final list more common labels were given. For example, the term 'Agreeableness' was given for a group of factors identified such as caring, friendliness, cooperation, trustworthiness, and calmness. The reason was to reduce the number of the final factors by making the prioritizing easier. Another reason is the principle of parsimony.

\section{Major Factors of Job Performance of the Cabin Crew on Customer Service of an Airplane from Prioritizing}

The fourth research question of the study is: What are the major factors which determine job performance of the Cabin Crew on customer service of an airplane as per the prioritization of managers and instructors who are responsible for performance management of the crew? In order to answer the research question, the prepared evaluation sheet was utilized and this sheet had the final list of the factors of job performance. 14 factors were included in the interview evaluation sheet for the purpose of prioritizing. These factors (their working definitions have been given within the brackets) are:

1. Attitude about Customers (the extent to which the employee believes in that customers are the most important stakeholder and excellent customer service is essential, feels the customer service interestingly, and has a behavioural tendency towards excellent customer service)

2. Attitude about Self (the extent to which the employee is aware of his or her own strengths and weaknesses, and his or her evaluation about his or her self-concept) 
3. Emotional Stability (the extent to which the employee is calm, secure, and reasonable without having frequent changes of mood)

4. Agreeableness (the extent to which the employee is cooperative, warm (friendly), trusting, tolerant, and good-natured)

5. Personal Character (the extent to which the employee has virtues such as honesty, humility, patience, benevolence, and respect and vices such as jealousy, deception, selfishness, anger, and hostility)

6. Job Satisfaction (the extent to which the employee is happy about his or job)

7. Job Involvement (the extent to which the employee engages in doing the job)

8. Organizational Commitment (the extent to which the employee is loyal to the organization)

9. Organizational Citizenship (the extent to which the employee has willingness to perform more than what he or she is supposed to perform for the success of the organization)

10. Supervision (the extent to which the employee on the job is overseen by his or her superior)

11. Competencies (the extent to which the employee has knowledge and skills to perform the duties of the job successfully)

12. Performance Evaluation (the extent to which the employee's job performance is formally assessed and the feedback is given for improvement)

13. Pay-for-Performance (the extent to which the employee is paid and rewarded according to his or her job performance; excellent performance gets excellent rewards while poor performance gets no rewards)

14. Work-Family Balance (the extent to which the employee does meeting company expectations/demands and family expectations/demands in the way that makes both the company/relevant superior and family members happy)

10 personnel were consulted in order to prioritize the above mentioned fourteen factors. The personnel included Head of Service Delivery (HOSD), Head of Human Resources (HOHR), Manager In-Flight Service and Delivery (MISD), Manager Onboard Quality Assurance and Training (MOQAT), Cabin Crew Development and Engagement Manager (CCDEM), Cabin Safety Manager (CSM), In-Flight Service Instructor 1, In-Flight Service Instructor 2, In-Flight Service Instructor 3, and In-Flight Service Instructor 4. They were requested to select 7 factors from the most important one, the next most important one and so on (seven options). Weights were introduced in the way that gave 7 points for the first option (the most important factor), 6 points for the second option, 5 points for the third option, 4 points for the fourth option, 3 points for the fifth option, 2 points for the sixth option, and 1 point for the seventh option. The results of ranking done by the personnel are given in Table 1. 
Table 1: Results of Ranking By Each Resource Person

\begin{tabular}{|c|c|c|c|c|c|c|c|c|c|c|}
\hline FACTOR & HOSD & HOHR & MISD & MOQAT & CCDEM & CSM & INS 1 & INS 2 & INS 3 & INS 4 \\
\hline $\begin{array}{l}\text { 1. Attitude about } \\
\text { Customers }\end{array}$ & 1 & 2 & 1 & 1 & 1 & 2 & 1 & 1 & 3 & 1 \\
\hline $\begin{array}{l}\text { 2. Attitude about } \\
\text { Self }\end{array}$ & 6 & 7 & & & 3 & & & 7 & & \\
\hline $\begin{array}{l}\text { 3. Emotional } \\
\text { Stability }\end{array}$ & & & & & 2 & 4 & & & 2 & 2 \\
\hline 4. Agreeableness & 7 & 1 & 2 & & & 1 & & & 1 & \\
\hline $\begin{array}{ll}\text { 5. } & \text { Personal } \\
& \text { Character }\end{array}$ & $(* 6)$ & 3 & & 2 & 5 & & 2 & & & \\
\hline $\begin{array}{ll}\text { 6. Job } \\
\text { Satisfaction }\end{array}$ & & & 5 & 7 & 6 & 3 & & 4 & & 7 \\
\hline $\begin{array}{ll}\text { 7. } & \text { Job } \\
& \text { Involvement }\end{array}$ & 5 & 4 & 3 & & & & 7 & 3 & & 6 \\
\hline $\begin{array}{ll}\text { 8. Organisational } \\
\text { Commitment }\end{array}$ & 2 & 5 & & 6 & 7 & 7 & & 5 & 6 & \\
\hline $\begin{array}{l}\text { 9. Organisational } \\
\text { Citizenship }\end{array}$ & 4 & 6 & & & & & & 6 & & \\
\hline 10. Supervision & & & & & & & & & & \\
\hline 11. Competencies & 3 & & 6 & 5 & & & 5 & 2 & 4 & 5 \\
\hline $\begin{array}{l}\text { 12. Performance } \\
\text { Evaluation }\end{array}$ & & & 4 & & & & 4 & & & \\
\hline $\begin{array}{l}\text { 13. Pay-for- } \\
\text { Performance }\end{array}$ & & & 7 & 3 & & 5 & 3 & & 5 & 3 \\
\hline $\begin{array}{l}\text { 14. Work-Family } \\
\text { Balance }\end{array}$ & & & & 4 & 4 & 6 & 6 & & 7 & 4 \\
\hline
\end{tabular}

Abbreviations:

HOSD - Head of Service Delivery

HOHR - Head of Human Resources

MISD - Manager In-Flight Services

MOQAT - Manager Onboard Quality Assurance and Training

CCDEM - Cabin Crew Development and Engagement manager

INS 1 - In-Flight Service Instructor 1

INS 2 - In-Flight Service Instructor 2

INS 3 - In-Flight Service Instructor 3

INS 4 - In-Flight Service Instructor 4

Table 2 presents the results of prioritizing.

As per the Table, there is one factor which has not been considered by any resource person and it was Supervision. According to the total weights the most important determinant of job performance of the Cabin Crew is attitude about customers while the least important factor was supervision. Attitude about customers, agreeableness, competencies, personal character, pay-for performance, job involvement, organizational commitment, and workfamily balance were found to be as the main eight determinants of job performance of Cabin crew according to the results of prioritizing. 
Table 2: Results of Prioritizing

\begin{tabular}{|l|l|l|}
\hline FACTOR & Total Weights & Rank \\
\hline 1. Attitude about Customers & 60 & 1 \\
\hline 2. Attitude about Self & 09 & 10 \\
\hline 3. Emotional Stability & 14 & 9 \\
\hline 4. Agreeableness & 28 & 2 \\
\hline 5. Personal Character & 22 & 4 \\
\hline 6. Job Satisfaction & 16 & 8 \\
\hline 7. Job Involvement & 20 & 5 \\
\hline 8. Organisational Commitment & 18 & 6 \\
\hline 9. Organisational Citizenship & 08 & 10 \\
\hline 10. Supervision & 00 & - \\
\hline 11. Competencies & 26 & 3 \\
\hline 12. Performance Evaluation & 08 & 11 \\
\hline 13. Pay-for-Performance & 22 & 4 \\
\hline 14. Work-Family Balance & 17 & 7 \\
\hline
\end{tabular}

\section{The Most Important Three Determinants}

The fifth research question of the study is: What are the three most important determinants of job performance of the Cabin Crew on customer service of an airplane as per the prioritization of managers and instructors who are responsible for performance management of the crew? Based on the assumption that the above mentioned resource personnel possess a high level of comprehensiveness with regard to the determinants of job performance of Cabin Crew, it was found that attitude about customers, agreeableness, and competencies are the three most important determinants of job performance of the cabin crew.

\section{Conclusion}

Determinants of job performance of Cabin Crew were studied in Sri Lankan setting through a systematic attempt which was both conceptual and empirical. The systematic attempt done to find out answers for the five research questions resulted in that job performance of the Cabin Crew on customer service of an airplane in an airline is very important owing to the pivotal role played and core nature; a variety of factors including competencies, personality qualities, attitudinal ones, organizational conditions etc may have effects on functioning as a successful cabin crew member; the possible factors which determine job performance of the Cabin Crew on customer service of an airplane as per the perception of different stakeholders include a set of factors some of which are attitude about customers, competencies, caring, friendliness, cooperation, career development, performance evaluation, personal character, pay-for-performance, work-family balance, trustworthiness, calmness, job involvement, job satisfaction, and emotional stability in addition to supervision, knowledgeableness of every aspect of the job, discipline, empowerment of the subordinates to take swift decisions to mitigate issues, and adherence to rules of service which were found from observations of the critical incidents; the major factors which 
determine job performance of the Cabin Crew on customer service of an airplane as per the prioritization of managers and instructors who are responsible for performance management of the crew include attitude towards customers, agreeableness, competencies, personal character, pay-for performance, job involvement, organizational commitment, and work-family balance; and the most important three factors from the finalized 14 factors were attitude about customers, agreeableness, and competencies. Implications of the findings are that the airline that wants to enhance job performance of Cabin Crew is required to develop and implement successfully appropriate training programs which ensure that the employees possesses right attitude about customers, high level of agreeableness and relevant competencies. Also the airline is supposed to incorporate a performance evaluation system that measures and improves attitude about customers, agreeableness, and competencies while having a reward system that reinforces the same. Furthermore, as a proactive strategy, recruitment and selection need to be done to get job candidates who are appropriate in terms of the above three most important factors.

\section{References}

Anastasiou, A. and Nathanailides, C. (2015), "Customer Satisfaction and Effective HRM Policies: Customer and Employee Satisfaction", International Journal of Social, Education,Economics and Management Engineering, Vol. 9, No. 1, pp. 253-256.

Benardin, H.J. and Russell, J.E., (1993), Human Resource Management: An Experiential Approach, New York: McGraw Hill Inc.

Borucki, C.C. and Burke, M.J. (1999), An examination of service-related antecedents to retail store performance, Journal of Organizational Behaviour, Vol. 20, pp. 943-962.

Bowen, D.E., Siehl, C. and Schneider, B. (1989), A framework for analyzing customer service orientations in manufacturing, Academy of Management review, Vol. 14, No. 1, pp. 7595.

Campbell, J. P. (1990), Modeling the performance prediction problem in industrial and organizational psychology, In: Dunnette MD, Hough LM, eds.

Das, K. (2004), h-CRM: The key to Lifelong Business Relationships, Kuala Lumpur: Synergy Media.

Dessler, G. (2013), Human Resource Management, $13^{\text {th }}$ ed, Boston: PEARSON.

DuBrin, A.J. (2000), Essentials of Management, Cincinnti: South-Western College Publishing.

DuBrin, A.J. (2009), Human Relations: Interpersonal, Job-Oriented Skills, $8^{\text {th }}$ ed, New Jersey: Economics and Management Engineering, Vol. 9, No.1, pp. 253-256.

Glueck, W.F. (1978), Personnel: A diagnostic approach, Revised ed., Dallas, Texas: Business Publications, Inc.

Griffin, M. A., Neal, A., and Parker, S. K. (2007), A new model of work role performance: Positive behavior in uncertain and interdependent contexts, Academy of management journal, Vol. 50, No. 2, pp. 327-347. https://doi.org/10.5465/AMJ.2007.24634438

Heracleous, L., Wirtz, J. and Pangarkar, N. (2009), Flying High in a Competitive Industry: CostEffective Service Excellence at Singapore Airlines, Singapore: McGraw-Hill. 
Hunter, J. E. (1986), Cognitive ability, cognitive aptitudes, job knowledge, and job performance, Journal of vocational behavior, Vol. 29, No. 3, pp. 340-362. https://doi.org/10.1016/0001-8791 (86)90013-8

Judge, T. and Bono, J. (2000), Five-Factor Model of Personality and Transformational Leadership, Journal of Applied Psychology, 85, No. 5, October, pp. 751-765.

Kiger, P. (2002), Why Customer Satisfaction Starts with HR, www.workforce.com/2002/08/08/why-customer-satisfaction-starts-with-hr/

Kottawatta, K.H.H. (2007), Impact of Attitudinal Factors on Job Performance of Executives and Non-Executive Employees in Apparel Industry in Sri Lanka, Sri Lankan Journal of Human Resource Management, Vol. 1, No.1, pp. 53-70.

Opatha, H.H.D.N.P. (2015), Organizational Behaviour: The Human Side of Work, Colombo: Department of HRM, University of Sri Jayewardenepura.

Ramawickrama, J., Opatha, H.H.D.N.P., and PushpaKumari, M.D. (2017), A Synthesis toward the Construct of Job Performance, International Business Research, Vol. 10, No. 10, pp. 66-81.

Schuler, R.S. (1998), Managing Human Resources, $6^{\text {th }}$ ed, New York: South-Western College Publishing.

Solomon, M.R., Suprenant, C, Czepiel, A.J. and Gutman, E.G. (1985), A Role Theory Perspective on Dyadic Interactions: The service Encounter, Journal of Marketing, Vol. 49, Winter, pp. 99-111.

Stewart, G. L., and Brown, K. G. (2009), HRM: Linking Strategy to Practice, John Wiley \& Sons, New York.

Szilagyi, A.D. (1981), Management and Performance, California: Goodyear Publishing Company, Inc.

Viswesvaran, C., and Ones, D. S. (2000), Perspectives on models of job performance, International Journal of Selection and Assessment, Vol. 8, No. 4, pp. 216-226. https://doi.org/10.1111/1468-2389.00151 